\title{
Matching colours in pictorial retouching: influence of the three colour dimensions and colour distortion phenomena
}

\author{
Ana Bailao | Sandra Sustić
}

\begin{abstract}
Our visual perception is strongly influenced by the anatomical structure of the eye and by lighting conditions. While looking at the painting, we perceive existing colour attributes, using retinal photoreceptors - cones - that serve our vision at higher luminance levels. Lighting, on the other hand, affects our colour discrimination as well as our perception of three dimensions of colour.

During the retouching process our visual system can be affected by multiple optical impressions that many painting conservators are not fully aware of. Colour distortion phenomena can impact our observation stealthily, while producing simultaneous contrasts and afterimages that interfere with our colour discrimination as well as our decisions in pigment mixing.

The aim of this paper is to analyse these optical properties and to provide practical guidelines that will minimize colour distortion. One of the proposals is the use of $18 \%$ reflective grey card to cover adjacent colours around the paint loss. This method can be adopted as a helpful implement for tuning our colour perception.
\end{abstract}

\section{Keywords:}

colour matching, retouching, visual perception, simultaneous contrasts, afterimages, grey card.

\section{O acerto de cores na reintegração cromática: a influência dos três atribu- tos da cor e dos fenómenos óticos de distorção visual}

\section{Resumo}

A nossa percepção visual é fortemente influenciada pela estrutura anatómica do olho e pelas condições de iluminação. Visualizamos os atributos de cor existentes na pintura através das células fotorreceptoras da retina - cones - que servem a nossa visão em níveis elevados de iluminação. A iluminação, por outro lado, afecta a nossa discriminação de cor, bem como a percepção das três dimensões da cor.

Durante o processo de reintegração cromática o nosso sistema visual pode ser afectado por vários fenómenos de distorção das cores que muitos conservadores de pintura não estão totalmente conscientes. São fenómenos que podem influenciar a nossa observação furtivamente, como o contraste simultâneo e o contrate sucessivo, e que interferem nas nossas decisões durante o processo de identificação e mistura de pigmentos.

O objectivo deste trabalho é analisar estes efeitos ópticos e fornecer algumas orientações práticas para minimização destas distorções visuais da cor. Uma das principais propostas é 
Matching colours in pictorial retouching:

influence of the three colour dimensions and colour distortions phenomena

Ana Bailao | Sandra Sustić

o uso de um cartão com $18 \%$ de reflectividade. Este método pode ajudar na percepção das cores circundantes de uma dada lacuna, evitando alguns destes fenómenos.

\section{Palavras-chave:}

ajuste de cor, reintegração cromática; percepção visual, contraste simultâneo, contraste sucessivo, cartão cinzento.

\section{Aciertos de colores en reintegración cromática: la influencia de los tres atributos de color y los fenómenos ópticos de distorsión visual}

\section{Resumen}

Nuestra percepción visual está fuertemente influenciada por la estructura anatómica del ojo y por las condiciones de iluminación. Visualizamos los atributos de color existentes en una pintura a través de las células fotorreceptores de la retina - conos - que utilizan nuestra visión en niveles elevados de iluminación. La iluminación, por otro lado, afecta a nuestra discriminación de color, así como la percepción de las tres dimensiones de color. Durante el proceso de reintegración cromática nuestro sistema visual puede verse afectado por varios fenómenos de distorsión de los colores, de los que muchos conservadores - restauradores de pintura no son plenamente conscientes. Son fenómenos que pueden influir en nuestra observación furtivamente, como el contraste simultáneo y el contraste sucesivo, y que interfieren en nuestras decisiones durante el proceso de identificación y mezcla de pigmentos.

El objetivo de este trabajo es analizar esos efectos ópticos y ofrecer algunas orientaciones prácticas para minimizar las distorsiones visuales del color. Una de las principales propuestas es el uso de un cartón gris con un $18 \%$ de reflectividad. Este método puede ayudar a la percepción de los colores circundantes de una laguna, evitando alguno de esos fenómenos.

\section{Palabras-clave:}

ajuste de color, reintegración cromática, percepción visual, contraste simultáneo, contraste sucesivo, cartón gris.

\section{Introduction}

For a conservator colour is one of the essential formal elements in restoration practice. Our perception of colour dictates our decision in the restoration process. But what exactly happens in our visual mechanism during the process of mixing and matching pigments? Which optical elements impact our colour perception? 


\section{Matching colours in pictorial retouching: influence of the three colour dimensions and colour distortions phenomena}

Ana Bailao | Sandra Sustić

Human colour vision and the science of colour are very elaborated subjects, which have numerous papers and textbooks that deal with this matter (Farnsworth, 1957; Chevreul, 1967; Padgham and Saunders, 1975; Kuppers, 1975; Hurvich, 1981; Aarnisalo, 1984: 135-138; Bruce and Green, 1990; Arend, 1991: 412-421; Andviews, 2003: 434-436; Dain, 2004: 276-293). Although exploration of colour perception had been initiated in the treatises of famous renaissance painters, writings from the 19th century onwards [1], fostered new principles drawn from physiological optics (Birren, 1976).

Colour was regarded as a complex phenomenon and one of the most intriguing interests through history, yet it remains a topic of debate among contemporary colour scientists. As in the case of visual arts, colour theory can be applied in retouching practice as a practical guidance to colour mixing and the optical interactions of specific colour combinations.

Therefore, it is necessary to give a better understanding of certain optical aspects of colour that affect our retouching practice. The first part of this article is dedicated to colour perception and aims to emphasize the importance of the three dimensions of colour in retouching practice. The second two sections deal with this issue in a practical way, where through examples of colour matching the authors will make evident a few associated problems that may occur during the process of retouching. Special attention is given to effects of visual distortion phenomena, such as simultaneous contrast and afterimage that may interfere with our decisions while mixing the pigments. Finally, the last section will offer some practical guidelines to avoid and/or resolve these issues and increase our precision in colour matching.

\section{The perception of colour in retouching practice}

There are two basic interpretations of colour: first, colour can be "objectively" explained as a physical phenomenon; and second, colour can be explained "subjectively" as a response to a physical stimulus, i.e. as a sensation [2].

When objects are illuminated, the light they reflect does not simply bounce off their surface. Rather, the light is entirely absorbed and then reemitted (Pasnau, 2008) In physical terms, that light constitutes a section of the electromagnetic spectrum ranging from approximately 400 to 700 nanometres in wavelength (Hecht, 105,106:2002). Human colour vision results from the stimulation of the eye by electromagnetic radiation in this range. Light incident on the retina is absorbed by photopigments in the various photoreceptors - rods and cones [3]. Due to the three types of cones that are sensitive to three different spectra, RYB (red, yellow, and blue) became a historical set of subtractive primary colours primarily used in painting. From this set secondary and tertiary colours can be derived, and together they form conventional artists' colour wheel (Jennings, 2003).

In general, each colour that is applied in painting can be considered as a point within a space defined by its three dimensions - hue, value and chroma [Figure 1]. This system was 
Matching colours in pictorial retouching:

influence of the three colour dimensions and colour distortions phenomena

Ana Bailao | Sandra Sustić

devised from the American painter and art teacher, Albert Munsell (1858-1918), who defined quantitative scales of colour dimensions (Birren, 1969: 7; Briggs, 2007)

In the Munsell colour system hue is defined as the quality by which we distinguish one colour from another. This dimension does not tell us whether the colour is dark or light, strong or weak; it merely refers to some point in the visible spectrum that yields the perceived colour (Cleland, 1921; Birren, 1969: 18-19). On the other hand, chroma is the intensity or strength of the hue (Birren, 1969: 23), i.e, a measure of the spectral "purity" of a colour, and of its difference from a neutral, achromatic stimulus. Finally, value - sometimes referred as lightness or brightness, is described as the quality by which we distinguish a light colour from a dark one (Birren, 1969: 20). Therefore, bright objects have higher value and lower amounts of grey, while dark objects have low value and larger amounts of grey.

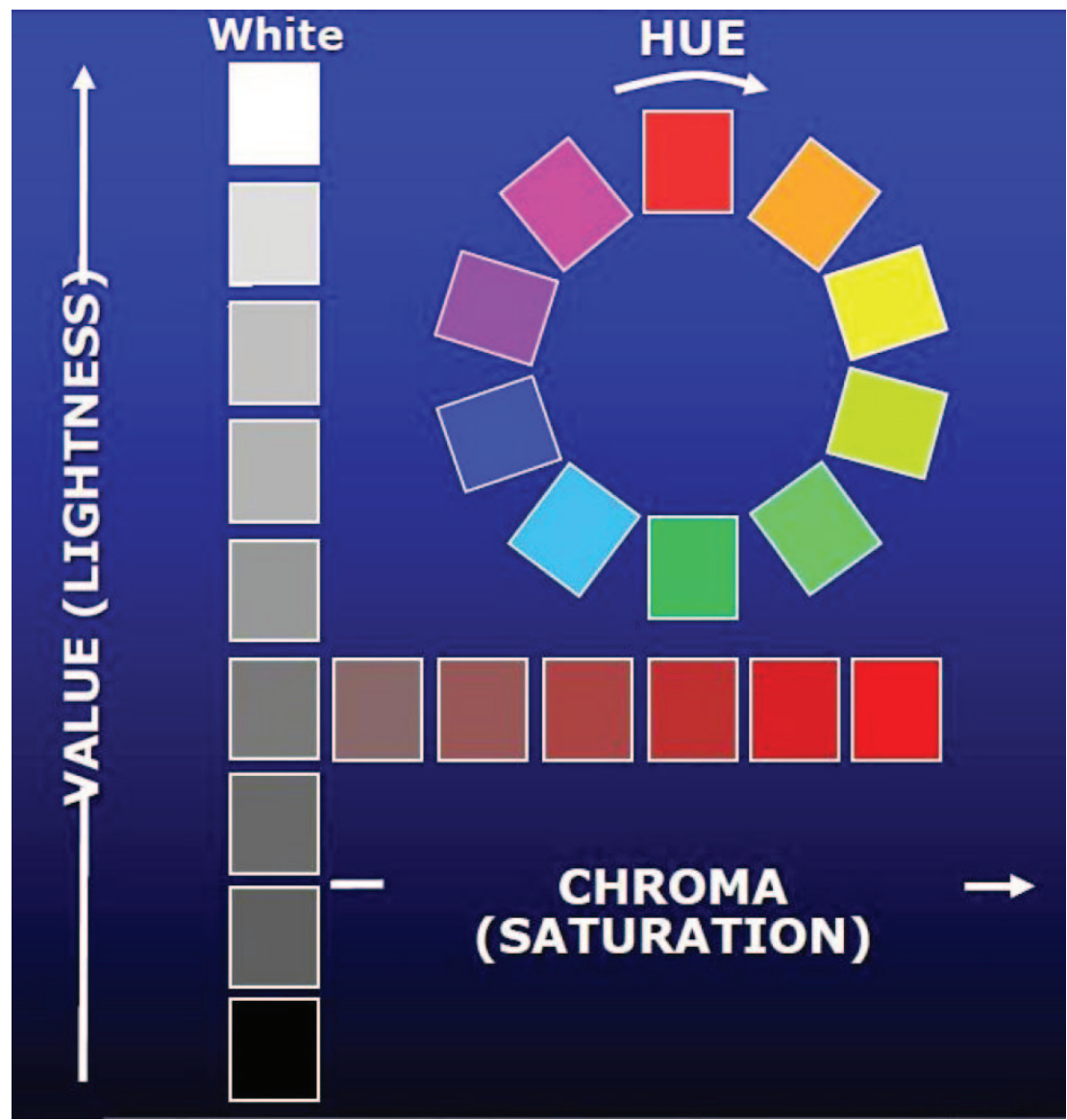

Figure 1 - Munsell Hue, Chroma and Value Chart

In order to make precise reconstruction of the selected colour in the painting, conservator must be aware of these colour attributes within the original paint layer. If we, for example, have to retouch some area in the painting using a blue pigment, our multiple applications of the paint will increase the chroma or intensity, but nevertheless the hue will remain the same. If we go further, and add more of the same pigment, the mixture will also appear 


\section{Matching colours in pictorial retouching: influence of the three colour dimensions and colour distortions phenomena}

Ana Bailao | Sandra Sustić

darker, thus the change in chroma has a corresponding change in value. If chroma increases, the value decreases, meaning that chroma and value are inversely related.

It has been observed that the eye tends to overestimate the lightness of some hues - like the deep reds and blues, and underestimate the lightness of others - like yellow and greens. For example, when we have a light red drape and a dark red drape we tend to select and reconstruct a similar red hue and forget chroma and lightness. Empirically some professionals add more white or black to modify hue, when, for instance, we should only add more layers of the same hue or a complementary colour [4].

If we want to retouch a paint loss in a bright sky area, we usually increase the value by using lighter pigments like titanium dioxide (which will lower the chroma) or perhaps by increasing the reflectivity of the surface with a proper varnish (Rie, 1987: 1-13; Rie et al, 2010: 134-143). Lowering value means that diminished light returns from the object illuminated, thus, more light is either being absorbed, scattered elsewhere, or transmitted.

Certain hues have more extensive value range than others and can retain their identity as they become darker. For example, blue remains recognizable as blue, even with a significant amount of grey added. Yellow and orange, on the other hand, lose their hue identities as they lower in value. Value influences the chroma and hue affects the appearance. However, in colour perception value and chroma are often confused because it is difficult to distinguish light from saturation.

\section{Colour matching and associated problems}

There are two major methods practiced today for retouching of losses on easel paintings invisible or imitative retouching and distinguishable retouching. In the first case, reconstructed colours need to be similarly or equally matched with the colour of the original paint layer, while, in the second case, the colour matching will depend on the techniques selected [5]. In addition, colour matching can be executed in two basic manners- equivalent and spectral colour matching. When we refer to equivalent colour matching, the reconstructed colour should ensure evenness between loss and original paint layer under typical lighting conditions, and yet it can vary under different sources of light. This is the most common colour matching used by conservators. Apart from considering many factors like the filler, texture, retouching medium, solvent, type of pigments, among others, conservator has to correctly evaluate the three colour dimensions and try to avoid colour vision distortions.

On the other hand, spectral matching aims to achieve equal spectral reflectances between the loss and the original paint layer that will remain constant under various lighting conditions. For this type of retouching, selected pigments and the medium mixtures need to be measured colorimetricly with the spectrophotometer. 


\section{Matching colours in pictorial retouching: influence of the three colour dimensions and colour distortions phenomena}

Ana Bailao | Sandra Sustić

For precise matching it is fundamental to have optimal lighting conditions (CIE D65, RCI $100,5500 \mathrm{~K}-6500 \mathrm{~K}$ ) (Johnston-Feller. 2001: 20, 21), yet it is necessary to ensure the precision of the match in every other conditions of illumination, in order to avoid metameric matches. Another important suggestion, when re-establishing colour loss using the mimetic technique is the selection of pigments with similar spectral curves [6] as in the original paint layer (Staniforth 1985: 101-11). The closer the curves of the two materials that need to be matched, the more successful will the colour match be [7].

However this is a difficult task. Accordingly, the conservator can try to reduce the chance of a colour mismatch by using the same colorant in the retouching as in the original paint. By doing so, he will presumably increase the closeness of the spectral match (Saunders, 2000: 3). However, this is not a guarantee for precise matching, due to the presence of minor impurities, crystallinity and extraction methods of natural pigments; whereas for manufactured pigments, the presence of extenders and adulterants can modify a pigment's reflectivity.

\section{Influence of the three colour dimensions (hue, chroma and value) and a few colour distortion phenomena}

When a conservator performs a retouch, he has to select the equivalent hue and then try to match chroma and value with the colour of the original painting. If one of these three colour dimensions is not right, the retouched area will be affected by the surrounding original colours. This phenomenon is called "simultaneous contrast" [Figure 2] Due to this effect, retouching techniques such as neutral tint and chromatic abstraction seem different depending on the localization of each loss in the painting. It also explains why it is difficult to get satisfactory results with these techniques, which can be perceived as neutral next to a coloured background, lighter under a black background and darker under a lighter background.
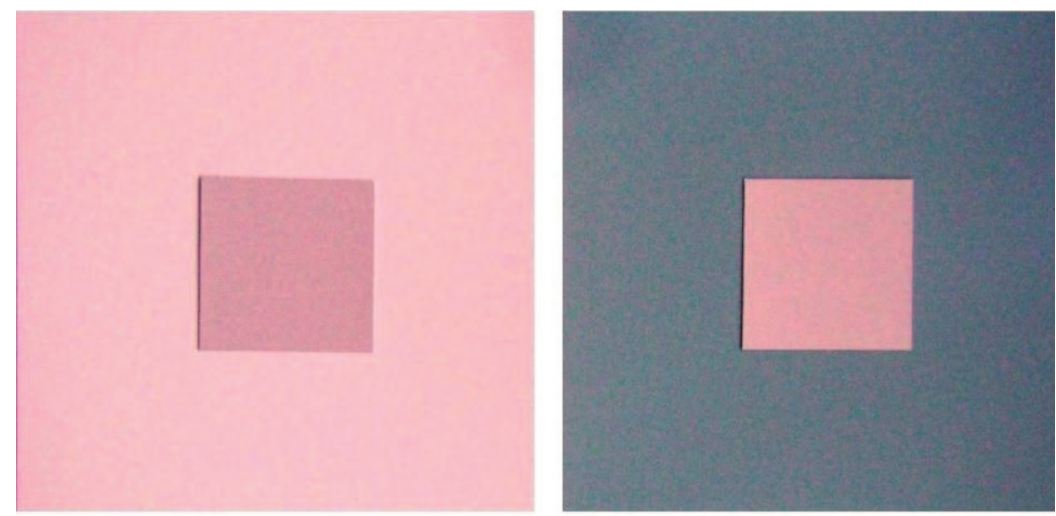

Figure 2 - Simultaneous contrast. The little square has the same hue, but seems different depending on the surrounding backgrounds. Munsell Simultaneous contrast kit. 


\section{Matching colours in pictorial retouching: influence of the three colour dimensions and colour distortions phenomena}

Ana Bailao | Sandra Sustić

While retouching a red colour, with a hue equivalent to Indian red (PR101), normally we can't get a perfect matching colour at once. First we have to match the saturation and the light of the hue selected. If the surrounding colour of the loss is a darker red, our PR101 appears lighter; if it is lighter, the opposite occurs. Due to the value of the original colour, the perimeter of the loss can appear larger or smaller - larger if the red is lighter and smaller is the red is darker. For example, if the original paint is a darker red, then we have to saturate our PR101 with additional layers of the same color. If this is not enough we have to add a complementary colour like green. In other case, if the original red is lighter, and we can't use white tint to adjust the value, we will have to use the transparency of white filler, and probably apply lighter yellow.

Hue influences the strength of simultaneous contrast. The contrast between blue green and red is different in strength and subjective effect from the contrast between yellow and violet. When retouching in a blue-green sky area, where a warmer and brighter colour is desirable, we can use orange or a red yellow; but otherwise when we are retouching with a bright yellow, and we add to much yellow to the loss, the only way to step back and get a darker yellow is to add violet.

Other colour vision distortions that can affect conservator's perception while retouching are "afterimages" or "successive contrast". There are positive and negative afterimages. A Positive afterimage can result from brief intense stimulation; whereas the negative occurs from prolonged, moderately intense stimulation of the cones. While a positive afterimage is easy to detect with photographic flash and specular solar reflections (when we look directly to the light and quickly turn off the light), negative afterimages appear after fixating on a coloured pattern. When the stimulus is removed, the observer sees a similar pattern in the complementary colour (Sperling, 1960: 1613; Kim and Francis, 2011: 1) [Figure 3]. This type of afterimage has more influence in retouching than positive afterimage.

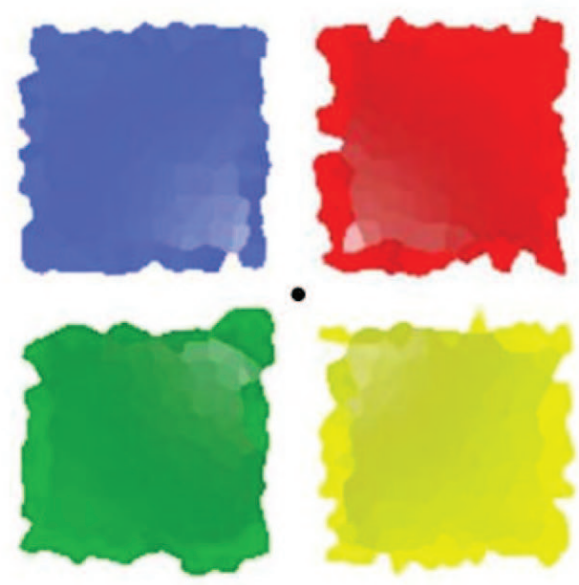

Figure 3 - Afterimage effect. Look at the black dot in the middle of the coloured squares for 5 or 10 seconds, and then look quickly over to the black dot on the right. We will see the afterimage of visual complements in the neutral white space. 


\section{Matching colours in pictorial retouching: influence of the three colour dimensions and colour distortions phenomena}

Ana Bailao | Sandra Sustić

The colour of a negative afterimage influences the apparent colour of surfaces viewed subsequently to the stimulus - a phenomenon also known as successive contrast (Albers, 2007: 35). It can occur under normal circumstances when our eyes don't stare fixedly at a single spot, but rather roam over the visual field of the painting. While performing mimetic or distinguish retouch, conservators are often dealing with the same single loss and colour for many hours. However, when the retouched area is finished and the light is removed from the retina, the receptors continue to be active for a short time and send a signal to the brain. Thus the conservator is constantly creating weak overlapping afterimages of which he is totally unaware.

If we have a loss within two adjacent areas of different colour, the colour we see for each will be a combination of the true colour of the area and the afterimage of the adjacent area. Therefore, after finishing one retouching session, it is necessary to rest at least a half an hour after beginning another one. The rest will prevent fatigue of the receptors and will also provide a clear view of the colour selection for the next loss.

When the receptors become fatigued after a period of exposure, they become less sensitive to further stimulation. For example, if we were retouching some loss in a red colour on a painting where the red colour dominates, after a while our red receptors will become fatigued in comparison with green and blue receptors. If we then look away at a white background - like the white filler of other loss - the red, green, and blue receptors will all be fully stimulated, but the red receptors will produce a diminished response. Thus we will see a blue-green afterimage. The afterimage will always be the complimentary colour of what we had been staring at.

If we have vivid red colour next to the loss we are treating, the red receptors in our roaming eyes will become fatigued while the blue and green receptors will remain fresh and capable for further stimulations. This can yield a perception of the loss as more blue-green than it really is.

To avoid such phenomena, the authors propose adaptation of $18 \%$ reflective grey card frequently used in photographic industry (Galdino, Vogel and Vander Kolk, 2001: 1334-1344; Devigus and Paul, 2006: 20-29) or the Munsell grey card named Color Control Standard [Figure 4]. If one of these cards is placed next or around the loss it is possible to evaluate three colour dimensions of the observed area with more precision. The card will work as a shield from background colours, preventing them from interfering with our perception [Figure 5]. 
Matching colours in pictorial retouching:

influence of the three colour dimensions and colour distortions phenomena

Ana Bailao | Sandra Sustić
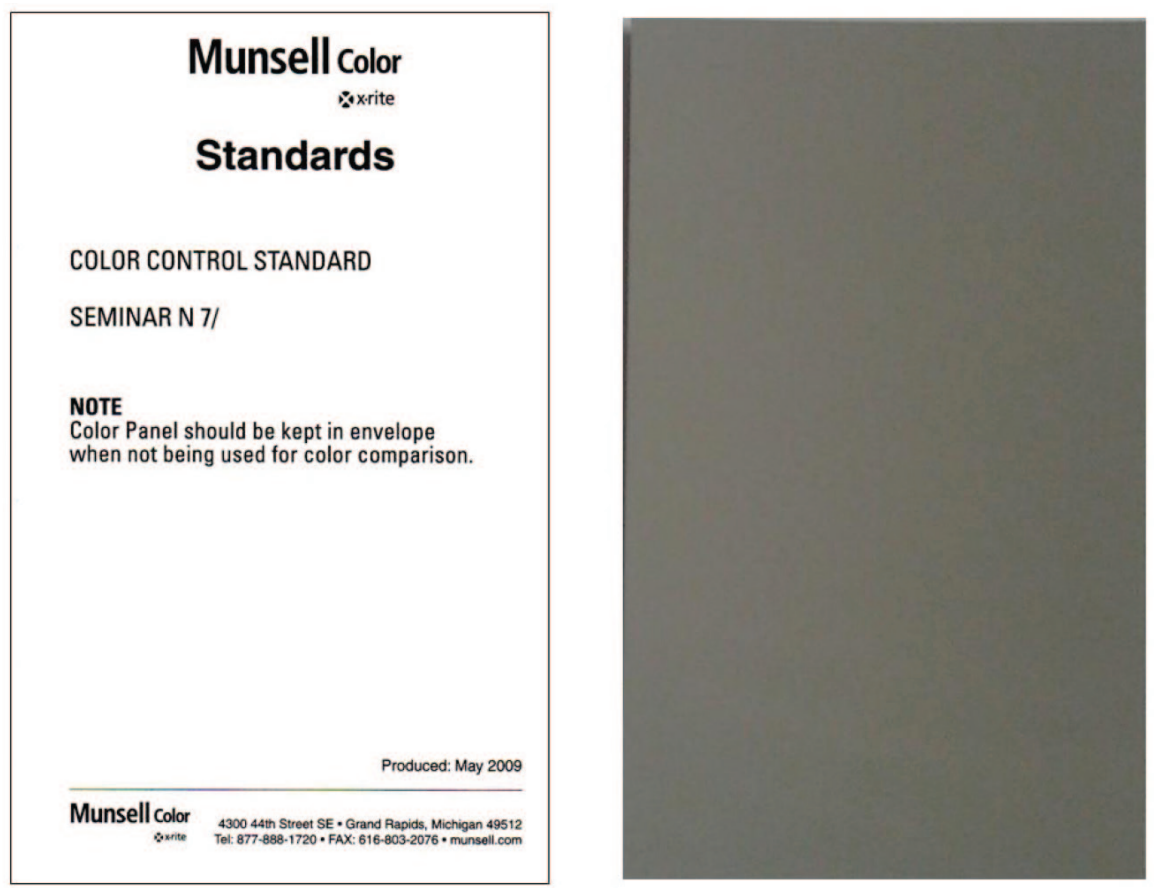

Figure 4 - Munsell Color Control Standard. Grey card used for colour comparison.

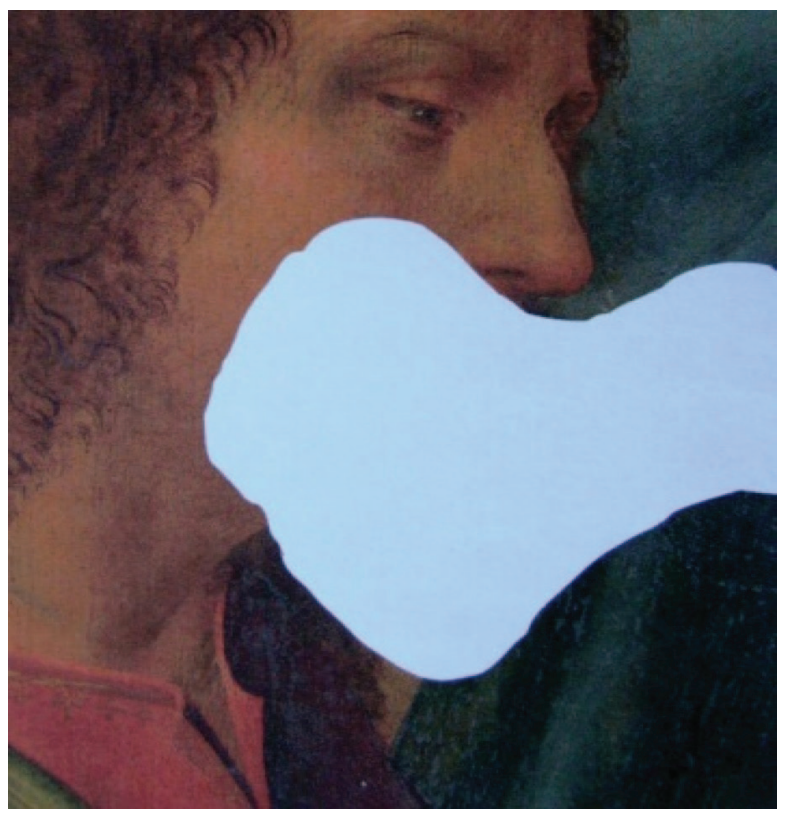

a)

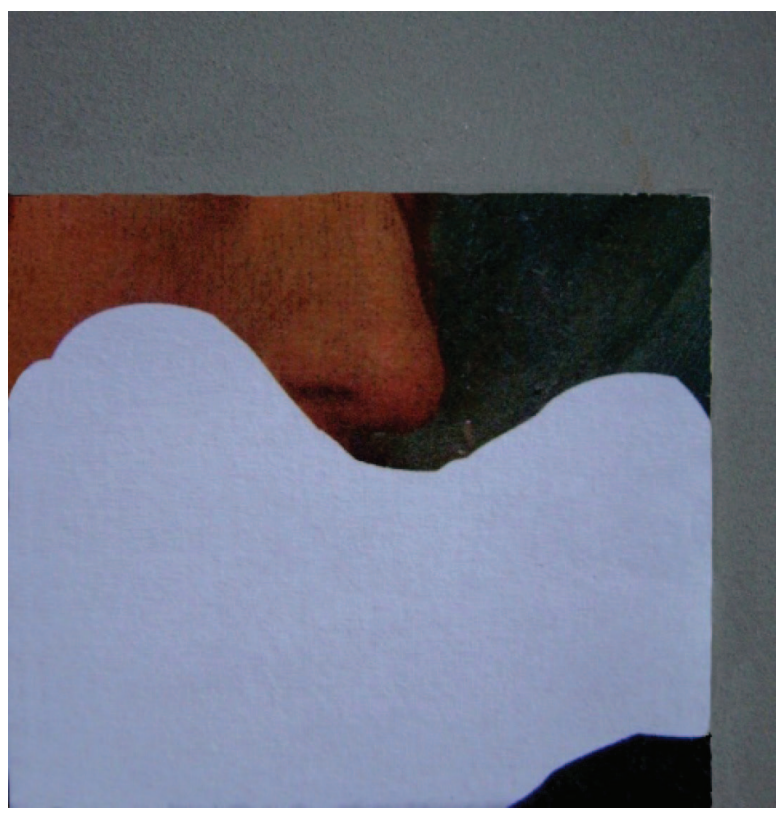

b)

Figure 5 - Evaluation of the surrounding colours of the loss with a $18 \%$ grey card: a) loss observation without a grey card; b) loss observation with the grey card. The pictures were taken under the same light and background conditions. In the first picture the missing area seems more yellowish when compared with the loss of the second picture.

During retouch, the background of our working environment can modify our colour perception as well. In order to avoid the effect of simultaneous contrast, it is important to work in a colour neutral environment and also to have distance from other paintings at the studio. 


\section{Matching colours in pictorial retouching: influence of the three colour dimensions and colour distortions phenomena}

Ana Bailao | Sandra Sustić

In a room coloured blue we shall perceive more orange than is actually present, since the complement colour of blue is orange. Thus, the ideal background colour would be neutral grey - like those used in the photographic studio. Neutral grey has no complimentary colour and is restful to the cones.

\section{Methodological guidelines to increase precision of colour matching}

There are four steps in the retouching methodology: chromatic and formal study, selection of the retouching technique, choice of the retouching material and retouching practice (Bailão, 2010; Bailão, 2010a; Bailão, 2011). With the objective to improve the last step in the procedure, next we will emphasize several practical guidelines that will comply with our intent - to perform accurate colour matching.

a. Our working environment should be equipped with optimal lighting conditions that will maintain our colour perception precise and constant. No matter what technique is being used, without a light source that approaches $5500 \mathrm{~K}-6500 \mathrm{~K}$, Colour Rendering Index (CRI) of 100, with the proper luminosity, it would be difficult to obtain accurate colour matching.

b. Retouching projects should be executed in a neutral grey environment, in order to prevent influences of ambient colours on our practice. Namely, if we look at a bright red wall, the cones in our eyes will saturate and fatigue quickly giving an afterimage of the complimentary colour blue-green. Thus it is possible, that our retouching area will be bluish in a different environment.

c. During the process of matching, the conservator has to focus his intention on the shape of the loss, the surface texture, and the three dimensions of colour (hue, chroma and value). Next to the hue, value is the second significant dimension when matching bright colours and shades. It is also important because it influences chroma - if we increase value, we decrease chroma.

d. It is necessary to analyse and choose the best colour that will give brightness to the hue that we are matching. In the case of distinguishable technique, the yellow hue is, normally, a means to simulate the value as well as the transparency of the white filler.

e. It is important to conduct the chroma compensation before application of a glossy varnish, because varnish will increase colour saturation.

f. Due to the eye fatigue, first impressions are usually the best ones. It is advisable to avoid focusing on the retouching area for to long in order to prevent hue accommodation and also to ask a professional colleague for a second opinion.

g. The best background for hue and chroma selection is a $18 \%$ (or lighter) reflective grey card like the Munsell grey card named Color Control Standard or the grey card 


\section{Matching colours in pictorial retouching: influence of the three colour dimensions and colour distortions phenomena}

Ana Bailao | Sandra Sustić

used in the photographic industry. These cards can be used to isolate the missing area that we attempt to retouch in order to avoid colour distortions. During the retouching process of each loss it is necessary to remove the card and step back from the painting to have a proper perception of the whole and of the retouched area. The card will also ensure better discrimination of the three colour dimensions, and thus we can select hues with more visual accuracy.

h. Surface texture determines the amount and direction of light scattering. Thus, when the type of a painting allows, we can also apply the convenient surface texture, and accordingly decrease the high value of a flat and extensive loss.

\section{Conclusion}

Colour theory can be adopted as a practical guidance in colour mixing and the visual interactions of specific colour combination in retouching practice. In order to make precise reconstruction of the selected colour in the painting, the conservator must be able to recognize the three dimensions of colour within the original paint layer. If one of these dimensions is faultily reconstructed, the perception of the retouched area will be affected by the surrounding original colour. This will initiate the production of colour distortions that will interfere with our decisions in resumed colour mixing.

Awareness of these phenomena and certain precautions can improve our colour matching. It has been observed that occasional eye rest during retouching will prevent fatigue of the receptors while providing a clear view of the colour selection. One of the most important factors in colour matching is the temperature of our light source that must be close to $5500 \mathrm{~K}-6500 \mathrm{~K}$. In addition the background colours of our working environment can as well modify our colour perception and thus it is advisable to work in neutral coloured areas.

To avoid mismatch in retouching, the authors also propose adaptation of $18 \%$ reflective grey card that is frequently used in photographic industry or the Munsell grey card named Color Control Standard. By placing the card next or around the loss, it is possible to evaluate three colour dimensions of the observed area with more precision.

\section{Acknowledgments}

This work has been supported by Fundação para a Ciência e a Tecnologia (FCT) and QREN - POPH, co-funded by the Portuguese Government and European Union by MCTES. This research was also partially supported by FCT scholarship SFRH/BD/ 69783/2010. Special thanks goes to Croatian Conservation Institute. 


\section{Matching colours in pictorial retouching: \\ influence of the three colour dimensions and colour distortions phenomena}

Ana Bailao | Sandra Sustić

\section{Notes}

[1] Philip Otto Runge (1810) devised one of the first colour order systems in three dimensions, while in 1839 M. E. Chevreul dealt with alternate and simultaneous contrast, afterimages and optical mixtures of colour (Birren,1976).

[2] Eugene Hecht has defined colour as an electrochemical manifestation of the sensorial system - eye, nerves and brain (Hecht, 2002: 106).

[3] Due to the size of the wavelength, there are three types of cones receptors- long $(L)$, middle (M) and short (S). Vision served only by cones is referred to as photopic vision, which is responsible for our colour perception (Seely, Stephens and Tate, 1997: 504; Pinto, 2001: 6-7; Forjaz, 2004: 18-10).

[4] Transparent colours always darken mixtures, because they work by removing light. Opaque colours tend to lighten a darker mixture, but their effect on lightness is more conditional (Briggs, 2007).

[5] According to Sarah Staniforth, the acceptability of matching colours when we are performing retouching depends on a number of factors including its level, texture of filler and paint, impasto, transparency and its colour (Staniforth, 1985: 101).

[6] According to Ruth Johnston-Feller "when the amount of power reflected or transmitted by a material is scanned across a particular region of the Spectrum, a curve may be plotted showing reflection or transmission as a function of wavelength. Such a curve is called a spectral curve or a spectrophotometric curve. The shape of this measured curve is often specific, providing a type of fingerprint characteristic of the chemical nature of the materials." (Johnston-Feller, 2001: 5).

[7] For example, a chrome red appears red because it absorbs light in the blue to green region of spectrum and reflects red, while the azurite pigment absorbs green and red light and yet it reflects only the blue light.

\section{References}

AARNISALO E. Testing of colour vision for vocational purposes. Acta Ophthalmologica Supplement, 161, 1984, pp. 135-138.

ALBERS, Josef. La interacción del color. Madrid: Alianza Editorial, 2007.

ANDVIEWS, N. Understanding colour vision. Trends in Cognitive Sciences, 7(10), pp. 434436. (2003). Available at: HTTP://Linkinghub.eLSEVIER.com/RETRIEVE/PII/S1364661303002249

AREND. L. Apparent contrast and surface color in complex scenes. In ROGOWITZ, B. E.; BRILL, M. H.; ALLEBACH, J.P. (editors). Proceedings of the SPIE, Human Vision, Visual Processing and Digital Display II, 1453, 1991, pp. 412-421. 


\section{Matching colours in pictorial retouching: \\ influence of the three colour dimensions and colour distortions phenomena}

Ana Bailao | Sandra Sustić

BAILÃO, Ana Maria dos Santos. Metodologia e técnicas de reintegração cromática em pintura de cavalete. Porto: Universidade Católica Portuguesa, 2010. Dissertação de Mestrado.

BAILÃO, Ana. Application of a methodology for retouching, CeROArt, No6, 2010a. Available at: HTTP://CEROART.REVUES.ORG/1603;

BAILÃO, Ana. Proposal of a methodology in chromatic reintegration. In V Congresso Internazionale "Colore e Conservazione", Le fasi finali nel restauro delle opere policrome mobili, Cesmar7, Saonara: il prato, 2011, pp. 226-227.

BIRREN, Faber (Editor). A Grammar of Color: A Basic Treatise on the Color System of Albert H. Munsell. New York: Van Nostrand Reinhold, 1969.

BIRREN, Faber. Color Perception in Art: Beyond the Eye into the Brain. Leonardo, 9 (2), (1976), pp. 105-110

BRIGGS, David. The Dimensions of Colour. Sydney, 2007. Available at: HTTP://www. HUEvALUECHROMA.COM/011.PHP.

BRUCE Vicki and GREEN Patrick. Visual Perception: Physiology, Psychology and Ecology. 2nd edition. Lawrence Erlbaum Associates, Hove UK, 1990.

CLELAND, T.M., A Pratical Description of the Munsell Color System, with Suggestions for its Use. Boston, Massachusetts, USA: Munsell Color Company, 1921. Available at: HTTP://www. APPLEPAINTER.COM/ (online edited version).

Chevreul, M. E., The Principles of Harmony and Contrast of Colors. New York: Van Nostrand Reinhold, 1967.

DAIN, S.J.. Clinical colour vision tests. Clinical and Experimental Ophthalmology, 87 (4-5), (2004), pp. 276-293.

DEVIGUS, A., \& PAUL, S. Preparing images for publication: part 1. The European journal of esthetic dentistry official journal of the European Academy of Esthetic Dentistry, 1(1), (2006), pp. 20-29.

Available at: HTTP://WwW.NCBI.NLM.NIH.GOV/PUBMED/19655473

FARNSWORTH, D. Manual: The Farnsworth-Munsell 100-hue test for the examination of Color Discrimination. New York: Munsell Color Co Inc., 1957.

FORJAZ, Vasco. Avaliação da função cromática em modelos de disfunção dos fotoreceptores e células ganglionares: perspectiva psicofísica. Coimbra: Universidade de Coimbra, 2004. Dissertação de mestrado.

GALDINO, G. M., VOGEL, J. E., and VANDER KOLK, C. A. Standardizing digital photography: it $\square$ s not all in the eye of the beholder. Plastic and Reconstructive Surgery, 108(5), 2001, pp. 1334-1344. Available at: HTTP://CONTENT.WKHEALTH.COM/LINKBACK/OPENURL?SID=WKPTLP:LANDIN GPAGE\&AN=00006534-200110000-00037

HECHT, Eugene. Óptica. 2.a ed. Lisboa: Fundação Calouste Gulbenkian, 2002. 


\section{Matching colours in pictorial retouching: \\ influence of the three colour dimensions and colour distortions phenomena}

Ana Bailao | Sandra Sustić

Jennings, Simon. Artist's Color Manual: The Complete Guide to Working With Color. Chronicle Books, 2003.

JOHNSTON-FELLER, Ruth. Color Science in the Examination of Museum Objects. Nondestructive Procedures. Los Angeles: The Getty Conservation Institute, 2001.

KIM, J., \& FRANCIS, G. Color selection, color capture, and afterimage filling-in. Journal of Vision, Association for Research in Vision and Ophthalmology, 11 (3), (2011), pp. 1-18. Available at: HTTP://www.JOURnALOFVISION.ORG/CONTENT/11/3/23.

KUPPERS, Harald. La couleur. Origine, methodologie, application. Fibourg: Office du Livre, 1975.

PADGHAM, C. A. and SAUNDERS. J. E., The Perception of Light and Colour. Academic Press, New York, 1975.

PASNAU, R. The event of color. In Philosophical Studies, 142 (3), (2009), pp. 353-369. Available at: HTTP://www.SPRINGERLINK.COM/CONTENT/M03U8464676JT2N8/

PINTO, Afonso Pedrosa. Relação entre a estrutura das funções de reflectância de Munsell e os quocientes da excitação dos cones. Braga: [s.n.], 2001. Tese de Mestrado em Física, Universidade do Minho.

RIE, E. René de la, The Influence of Varnishes on the Appearance of Paintings. Studies in Conservation. Londres: International Institute for Conservation of Historic and Artistic Works, 32 (1987), pp. 1-13.

RIE, E. René de la, John K. Delaney, Kathryn M. Morales, Christopher A. Maines and Li-Piin Sung, Modification of surface roughness by various varnishes and effect on light reflection. Studies in Conservation. Londres: International Institute for Conservation of Historic and Artistic Works, 55 (2010), pp. 134-143.

SAUNDERS, David. Retouching: colour vision and optical considerations. In Conference 2000; Retouching Filling. Oxford: Association of British Picture Restorers, 2000, p. 3-9.

SEELY, Rod R.; STEPHENS, Trent D.; TATE, Philip. Anatomia e Fisiologia. Lisboa: Lusodidacta, 1997.

SPERLING, G. Negative Afterimage without Prior Positive Image. Science, 131(3413), (1960), pp. 1613-1614. Available at: HTTP://DOI.APA.ORG/?UID =1961-00146-001

STANIFORTH, Sarah. Retouching and colour matching: the restorer and metamerism. Studies in Conservation. Londres: International Institute for Conservation of Historic and Artistic Works, 30 (3), (1985), pp. 101-111. 
Matching colours in pictorial retouching:

influence of the three colour dimensions and colour distortions phenomena

Ana Bailao | Sandra Sustić

\section{Biographical notes}

Ana Bailão - Conservator-restorer. Ana Bailão has a diploma in Conservation and Restoration by the Polytechnic Institute of Tomar (2005) and has a master's degree in Painting Conservation by the Portuguese Catholic University (2010). The master research was about methodologies and techniques of retouching. Now, she is currently a PhD student in Conservation of Paintings at the same university, in collaboration with the Centro de Investigação em Ciência e Tecnologia das Artes (CITAR) and the Instituto del Patrimonio Cultural de España (IPCE). Her doctoral research is about the criteria and methodologies which might help to enhance the quality of painting retouching. Since 2004 she practices conservation and restoration in her own studio in Lisbon.

Contact: ANA.BAILAO@GMAIL.COM

Sandra Sustic - Conservator-restorer. Sandra Sustic has a diploma in conservation-restoration of easel paintings and polychrome wood. She is currently pursuing a Ph.D. in Art History at the Faculty of Philosophy in Zagreb, Croatia. Her doctoral research deals with the history of conservation-restoration practice in Croatia. She works as a conservator-restorer at the Croatian Conservation Institute on the Department of easel paintings and polychrome wooden objects. Her main interests are conservation and restoration of paintings, history of conservation practice, theoretical and practical doctrines of retouching paintings and historically accurate reconstructions of old master paintings. Her projects are presented through publications, lectures, exhibitions and presentations in Croatia and abroad.

Contact: SUSTIC@H-R-Z.HR - WWW.REPIC-ART.COM 